\title{
Loading the primary caregiver of paediatric cancer patients in the Cuban Institute of Oncology and Radiobiology
}

\author{
Mariuska Forteza Sáez ${ }^{1 *}$, Dra María del Carmen Llanta ${ }^{2}$, Jorge A Grau Abalo², Débora García Socarrás ${ }^{1}$ and Dra Migdalia Pérez Trejo ${ }^{1}$ \\ ${ }^{1}$ Department of Oncopediatric, National Institute of Oncology and Radiobiology, Cuba \\ ${ }^{2}$ Department of Psychology, National Institute of Oncology and Radiobiology, Cuba
}

\begin{abstract}
Introduction: Cancer is a disease of high incidence among children and the patients need a caregiver during the treatment.

Objective: To describe the sociodemographic and clinical variables and assess the burden of the primary caregiver of children and adolescents hospitalized in the service Onco paediatrics the National Institute of Oncology and Radiobiology of Cuba (INOR) cancer.

Materials and methods: Exploratory, observational-descriptive study during January to December 2016 in the INOR. The universe consisted of all primary caregivers of paediatric patients who were admitted in the mentioned period, an intentional sample (248 caregivers) depending on the availability to participate in the investigation was taken. Summary measures for qualitative variables were used: absolute and relative frequencies and for evaluating the objective burden $Z$ arit method was used. The analysis was performed with SPPS, version 21.0.
\end{abstract}

Results: There was a predominance of women with college degree education by caregivers. An intense overload mostly related to physical overload of carers in $90 \%$ was obtained.

Conclusions: Overloading may be closely related to both the impact of care, the complexity of the actions, time care, coping resources, physical and emotional state of the caregiver

\section{Introduction}

Malignant neoplasms account for 2 to $5 \%$ of cancers in the world, the second cause of death in the subgroup from 0 to 4 years and the third in the group of 5 to 18 years, depending on the diagnosis. Worldwide, figures of $68 \%$ are reported for all cancer sites in children $[1,2]$.

In Cuba, between 400 and 450 new cases are presented annually, according to the National Cancer Registry. Cancer patients have prolonged and complex treatments. They are based, mainly, on the administration of treatments such as chemotherapy and surgery independently, or combined among them, in the function of histology, clinical stage and the functional status of each patient $[3,4]$.

With the diagnosis of a serious or prolonged illness, not only the patient has important changes in his life, but also the whole family dynamic has been affected by the physical and psychic repercussions of the disease. Its impact on the family can lead to painful and devastating effects. When the disease is cancer, the situation worsens, it is an entity that stigmatizes and is feared by the population, in virtue of the suffering it causes the patient and the family [5]. Hospitalization represents a crisis for the whole family. It is evident that the deprivation of daily activities, such as the function of hospitalization, the modification of the sensitive and relevant form of the behaviour of the patient and their closest relatives [6].

This situation in turn affects the risk of caregivers of physical and emotional problems. Many of them have the feeling of feeling physically and emotionally trapped, including feelings of guilt that can lead to claudication or inability to continue to meet the demands of their sick family member $[7,8]$.
Caregivers are related to the physical, psychological and socioeconomic order, and the whole with stress and interference in the management of the disease.

It is why the authors of this research were given the task of evaluating the burden of primary caregivers; in the period from January 2014 to June 2015, in the Paediatrics Room of the Institute of Oncology and Radiobiology.

\section{General objectives}

To describe the socio-demographic and clinical variables and to evaluate the burden of the primary caregiver of children and adolescents with cancer hospitalized in the Oncopediatric service of the National Institute of Oncology and Radiobiology of Cuba (INOR).

\section{Patients and methods}

An exploratory, observational-descriptive and cross-sectional study was conducted in the period from January 2014 to June 2015 in the Oncopediátria service of the National Institute of Oncology and Radiobiology of Cuba.

${ }^{\star}$ Correspondence to: Dra Mariuska Forteza Sáez, Department of Oncopediatric. National Institute of Oncology and Radiobiology, Cuba, E-mail: mforteza8324@gmail.com

Key words: caregiver burden, quality of life, child care

Received: February 04, 2019; Accepted: March 14, 2019; Published: March 18, 2019 
The universe was constituted by all the primary caregivers of pediatric patients who were admitted in the mentioned period, an intentional sample was taken (448 caregivers) according to the availability to participate in the research.

Eligibility criteria were: All primary caregivers of hospitalized cancer patients. That they agreed to participate in the study (informed consent).

The exclusion criteria were : Primary caregivers who did not want to participate in the study. That they did not have informed consent.

\section{Statistical methods}

In the research, a survey prepared by the researchers of the subject was used to characterize the sociodemographic and clinical variables (age, sex, education, histological diagnosis, treatment used), and to evaluate the objective load the Zarit method was used. Summary measures were used for qualitative variables: absolute and relative frequencies. The analysis was performed with SPPS, version 21.0.

\section{Ethical aspects of the study}

The consent of each caregiver who participated in the study was requested in written and verbal form, clarifying that their participation was totally voluntary and that they could stop answering the instrument at the time they considered it. The completion of the instrument was done anonymously, using a file number only known by the authors of the investigation. The investigative tasks executed did not imply physical or psychic affectations to the participants.

\section{Results}

A total of 448 primary caregivers of pediatric patients with malignant diseases in the selected period were evaluated; Of these, 118 presented a diagnosis of tumors of the central nervous system, followed by lymphomas and bone tumors, with an average time of disease progression of 1.7 years. The most used treatment modality was chemotherapy and $30 \%$ of patients received palliative care. Table 1.

The caregivers' average age was 35 years. Caregivers were mostly women (64\%) and married (75.0\%). Most of them had some college, college degree or higher (91.6\%), did not receive help from other people for care (20.5\%), Table 2.

Regarding the level of overload, it is observed that most of the caregivers showed an intense overload of $78.7 \%$, while the remaining $20 \%$ perceive the light load, the most frequent relationship of the primary caregivers with the patient was the mother $(63.2 \%)$, followed by the father $27.2 \%$, and the uncles by $4 \%$. While the mother and father accounted for $63.2 \%$ and $27.2 \%$ respectively of the study population. Therefore, there is a direct relationship of overload with parents. Table 3.

Table 1. Histological diagnosis of paediatric patients and time of evolution of the disease

\begin{tabular}{|c|c|c|c|c|c|c|}
\hline \multirow{2}{*}{ Histological diagnosis } & \multirow{2}{*}{ No } & \multirow{2}{*}{$\%$} & \multicolumn{3}{|c|}{ Treatment } & \multirow{2}{*}{$\begin{array}{c}\text { Time of evolution of the } \\
\text { disease in years }\end{array}$} \\
\hline & & & Chemotherapy & Radiotherapy & Surgery & \\
\hline SNC tumours & 118 & 26 & 100 & 118 & 90 & 1 \\
\hline Non-Hodgkin lymphoma & 99 & 22 & 99 & 17 & 0 & 1,6 \\
\hline Hodgkin lymphoma & 91 & 20 & 91 & 56 & 0 & 2 \\
\hline Osteosarcoma & 54 & 12 & 54 & 0 & 54 & 1,8 \\
\hline Ewing's sarcoma & 48 & 11 & 48 & 19 & 48 & 1, \\
\hline Wilms' Tumour & 20 & 5 & 20 & 6 & 20 & 3 \\
\hline Germ cell tumour & 15 & 3,3 & 15 & 1 & 15 & 1,6 \\
\hline Neuroblastoma & 3 & 0,7 & 3 & 0 & 3 & 2 \\
\hline Total & 448 & 100 & 430 & 217 & 230 & 1,7 \\
\hline
\end{tabular}

Table 2. Parent Demographics ( $\mathrm{N}=448$ families)

\begin{tabular}{|c|c|}
\hline Caregiver characteristics & $(n=448)$ \\
\hline Age: (years) & $35(23-47)$ \\
\hline \multicolumn{2}{|l|}{ Gender } \\
\hline Female & $287(64 \%)$ \\
\hline Male & $161(36 \%)$ \\
\hline \multicolumn{2}{|l|}{ Employment situation } \\
\hline Housewife & $279(62.3 \%)$ \\
\hline Employed & $135(30.1 \%)$ \\
\hline Unemployed & $34(7.6 \%)$ \\
\hline \multicolumn{2}{|l|}{ Education } \\
\hline Less than high school diploma & $6(1.3 \%)$ \\
\hline High school diploma & $32(7.1 \%)$ \\
\hline Some college & $246(54.9 \%)$ \\
\hline College degree or higher & $164(36.7 \%)$ \\
\hline \multicolumn{2}{|l|}{ Marital status } \\
\hline Married & $336(75.0 \%)$ \\
\hline Divorced/widowed & $55(12.4 \%)$ \\
\hline Single & $57(12.7 \%$ \\
\hline \multicolumn{2}{|c|}{ Received help to take care of the child } \\
\hline No & $92(20.5 \%)$ \\
\hline Yes & $356(79.5 \%)$ \\
\hline
\end{tabular}


Table 3. Overload level according to kinship

\begin{tabular}{|c|c|c|c|c|c|c|c|c|c|c|c|}
\hline \multirow{3}{*}{$\begin{array}{c}\text { Overload level } \\
\text { No overload (22-46 points) }\end{array}$} & \multicolumn{11}{|c|}{ Relationship } \\
\hline & \multirow{2}{*}{$\begin{array}{c}\text { Father } \\
\text { \% }\end{array}$} & \multirow{2}{*}{$\begin{array}{c}\begin{array}{c}\text { Mother } \\
\text { \% }\end{array} \\
0 \\
(0)\end{array}$} & \multicolumn{2}{|c|}{ Brothers\% } & \multicolumn{2}{|c|}{$\begin{array}{l}\text { Uncles } \\
\%\end{array}$} & \multicolumn{2}{|c|}{$\begin{array}{c}\text { Stepmother } \\
\%\end{array}$} & \multicolumn{2}{|c|}{$\begin{array}{c}\text { Stepfather } \\
\%\end{array}$} & \multirow{2}{*}{$\begin{array}{l}\text { Total } \\
6(1.3)\end{array}$} \\
\hline & & & 2 & 0,4 & 1 & 0,2 & 1 & 0,2 & 1 & 0,2 & \\
\hline Overload mild (47-55 points) & $15(3,3)$ & $68(15,2)$ & 4 & 0,9 & 0 & 0 & 3 & 0,7 & 2 & 0,4 & $92(20)$ \\
\hline Overload Intense (56-110 points) & $106(23,6)$ & $215(48)$ & 0 & 0 & 17 & 3,8 & 0 & 0 & 12 & 2,7 & $350(78.3)$ \\
\hline Total & $122(27.2)$ & $283(63,2)$ & 6 & 1,3 & 18 & 4 & 4 & 0,9 & 15 & 3,3 & $448(100)$ \\
\hline
\end{tabular}

\section{Discussion}

The present study results permit a broad discussion on how the cancer diagnosis and treatment in children affect caregivers' lives. The caregivers' average age (35 years) bordered on the age demonstrated in different studies of caregivers to children with cancer, as well as caregivers to children with tumors of the central nervous system, followed by lymphomas [9].

Among caregivers, women predominated, specifially the mother, compatible with other studies, in which female caregivers exceeded $70 \%[10-12]$.

In general, the mother believes that "nobody can rise up to her to take care, protect and see to her child's needs. Most caregivers (79.7\%) were married/had a fied partner - lower than for caregivers of children with brain tumor $(93.3 \%)[13,14]$. This lower rate can be due to the fact that, according to the Cuban Institute of Demographic and Statistics, the number of separations and divorces has been increasing in Cuba: in 2014 , for every four weddings, one dissolution was registered $[15,16]$.

As for employment, $62.3 \%$ did housework and $7.6 \%$ were unemployed, totaling $69.9 \%$ of caregivers without monthly income. Studies demonstrate that, when one of the children has cancer, employment contracts are broken due to the need for organization for child care and treatment, compromising family income [11]; many caregivers end up losing their job after the diagnosis, due to the diffiulty to reconcile care and work activities [14]. Based on these data, the report on the caregivers' lack of need to remain absent from work is understandable (69.9\%), as most informed they were housewives or unemployed. Despite the distancing mentioned in literature between other family members and the caregiver, caregivers also develop other activities, as most of them have other children, like in the present study with an average 2.7 children [17]. Also, 20.5\% of caregivers did not receive help to take care of the sick child or see to treatment demands (resources, including time and money) [18].

Our fidings regarding the existing correlation between the caregiver's average burden, are similar to fidings of researchers who looked at symptoms/disorders in mothers to children recently diagnosed with cancer regarding their adjustment trajectory and concluded that symptoms/disorders are common among parents to children with cancer during treatment, and that psychosocial interventions should be used to enhance parents and children's long-term wellbeing.

It should be highlighted that mental health alone was responsible for $25.55 \%$ of this burden observed that mental health was also the domain that most collaborated with the care burden (24.0\%).

\section{Conclusions}

There was a predominance of females in caregivers, with a university level of education, and an age range between 30 and 45 years. The percentage of levels of overload in the caregivers reported that most of them experienced intense overload. The analysis of overload according to kinship reveals that mothers and fathers experience mild and intense overload. The overload could be closely related to the impact dimension of care, the complexity of the actions, the time of care, the coping resources, the physical and emotional state of the caregiver.

\section{Conflicts of interest}

No potential conflict of interest exists.

\section{References}

1. Abad Steve ATO, Tomo I (2009) Publicaciones Permanyer. Mallorca, Barcelona.

2. Hagop MK, Wolff CK (2007) The MD Anderson manual of medical oncology. Houston.

3. National Cancer Registry (2015) National institute of oncology and radiobiology Havana, Cuba.

4. Ministry of Public Health (2016) Statistical health yearbook. Havana, Cuba.

5. Wijesinghe CJ, Cunningham N, Fonseka P, Hewage CG, Ostbye T (2014) Factors associated with caregiver burden among caregivers of children with cerebral palsy in Sri Lanka. Asia-Pacific J Public Heal 27:85-95.

6. Angarita VOM, Lizcano OF, Velazquez AN (2012) Overload of the oncological patient caregivers' users of the Cancer Clinic, in San José de Cúcuta. Investig. Sick Image Desarr 14: 85-95.

7. Bayes R. Caring for the caregiver. Caregiver evaluation and social support. Analysis of the psychological resources and emotional support of the caregiver. FCE. Mexico.

8. Zarit R, Back yP (2011) Hidden victims of Alzheimer disease families. under stress NYU Press. New York.

9. Hildenbrand AK, Clawson KJ, Aderfer MA, Marsac ML (2011) Coping with pediatric cancer: strategies employed by children and their parents to manage cancer-related stressors during treatment. J Pediatr Oncol 28: 344-54. [Crossref]

10. Harper FWK, Goodlett BD, Trentacosta CJ, Albrecht TL, Taub JW (201) Temperament, personality, and quality of life in pediatric cancer patients. J Pediatr Psychol 39: 459468.

11. Harper FWK, Penner LA, Peterson A, Albrecht TL, Taub J (2012) Children's positive dispositional attributes, parents' empathic responses, and children's responses to painful pediatric oncology treatment procedures. J Psychosoc Oncol 30: 593-613. [Crossref]

12. Kudubes AA, Bektas M, Ugur O (2014) Symptom frequency of children with cancer and parent quality of life in Turkey. Asian Pac J Cancer Prev 15: 3487-3493. [Crossref]

13. WHO International Agency for Cancer Research (2014) International Childhood Cancer Day. World Cancer Rep.

14. Eisenberg N, Smith CL, Spinrad TL (2011) Effortful Control: Relations with emotion regulation, adjustment, and socialization in childhood. In: Vohs, KD.; Baumeister, RF., editors. Handbook of Self-Regulation. $2^{\text {nd }}$ edn. The Guilford Press. New York.

15. Valdés J, Yohanka El (2014) divorcio en Cuba. Características generales y efectos para la familia. En publicación: Familia y Diversidad en América Latina. Estudios de casos. Robichaux, David. CLACSO, Consejo Latinoamericano de Ciencias Sociales, Buenos Aires.

16. Lund L, Ross L, Petersen MA, Groenvold M (2014) Cancer caregiving tasks and consequences and their associations with caregiver status and the caregiver's relationship to the patient? a survey. BMC Cancer 14: 1-13. 
17. Black DS, Fernando R (2014) Mindfulness training and classroom behavior among lower-income and ethnic minority elementary school children. J Child Fam Stud 23: 1242-1246.
18. Christopher JT, Felicity WKH, Terrance LA (2017) Pediatric Cancer Patients' Treatment-Related Distress and Longer-Term Anxiety: An Individual Differences Perspective. J Dev Behav Pediatr 37: 753-761.

Copyright: (02019 Sáez MF. This is an open-access article distributed under the terms of the Creative Commons Attribution License, which permits unrestricted use, distribution, and reproduction in any medium, provided the original author and source are credited. 